\title{
Association of Maternal Vitamin D with Neonatal Vitamin D Status and Birth Weight in Urban Population of Bangladesh: A Cross Sectional Study
}

\section{Md. Mostafijur Rahman ${ }^{1, a}$, Saimon Miah ${ }^{1, a}$, Sonia Tamanna ${ }^{1}$, Md. Bayejid Hosen ${ }^{1}$, Tasnin Akter ${ }^{1}$, TH Johra ${ }^{2}$, Yearul Kabir ${ }^{1}$ and M Zakir Hossain Howlader ${ }^{1 *}$}

${ }^{1}$ Laboratory of Nutrition and Health Research, Department of Biochemistry and Molecular Biology, University of Dhaka, Dhaka, Bangladesh

${ }^{2}$ Consultant, Department of Obstetrics and Gynecology, Islami Bank Hospital, Dhaka, Bangladesh

${ }^{a}$ Authors contributed equally in this study

*Corresponding Author: M Zakir Hossain Howlader, Professor, Department of Biochemistry and Molecular Biology, University of Dhaka, Dhaka, Bangladesh.
Received: October 29, 2020

Published: November 27, 2020

(C) All rights are reserved by Md. Mostafijur

Rahman and Saimon Miah., et al.

\begin{abstract}
Background: Vitamin D deficiency during pregnancy leads to poor neonatal development which has serious consequences during the later part of life. The aim of the study was to evaluate maternal and umbilical cord blood 25[OH] D concentrations and their association with birth weight.

Methods: Pre-delivery maternal venous blood within a week before delivery and paired matched neonatal cord blood samples were collected from 75 pregnant women. Serum 25[OH] D was measured by high-performance liquid chromatography. Serum calcium, phosphorus, and alkaline phosphatase activity were measured by colorimetric methods.

Results: Mean maternal serum 25[OH] D was $46.45 \pm 5.02 \mathrm{ng} / \mathrm{ml}$, and cord blood 25[OH] D was $21.89 \pm 2.27 \mathrm{ng} / \mathrm{ml}$. The serum $25[\mathrm{OH}] \mathrm{D}$ level of the mothers and the neonates were significantly associated $(\mathrm{P}<0.01)$ with a linear correlation coefficient of $\mathrm{r}=$ 0.49 . The mean birth weight of neonates was $2.83 \mathrm{~kg} \pm 0.38$ and $22 \%$ of the neonates had low birth weight (LBW) (2.33 \pm 0.17 ). Average birth weight of normal babies was $2.97 \pm 0.30$. The mean maternal $25[\mathrm{OH}] \mathrm{D}$ level of mothers with normal birth weight babies $(\mathrm{n}=58 ; 77.33 \%)$ was significantly higher $(50.41 \pm 5.00 \mathrm{ng} / \mathrm{mL})$ than that $(28.24 \pm 6.87 \mathrm{ng} / \mathrm{mL})$ of mothers with LBW babies $(\mathrm{p}<$ $0.0001)$. There was a high degree of positive correlation between maternal $25[\mathrm{OH}] \mathrm{D}$ status with neonate's birth weight $(\mathrm{r}=0.593$, $\mathrm{p}<0.01)$.

Conclusion: The results obtained in this study show that there is significant correlation between maternal vitamin D with neonatal birth weight in a cross-sectional urban population of Bangladesh.
\end{abstract}

Keywords: Serum 25[OH] D; Pregnancy; Cord Blood; Low Birth Weight

\section{Introduction}

Vitamin D is a fat soluble secosteroid formed mostly in human skin by exposure to sunlight, with a small fraction coming directly from the diet $[1,2]$. Either endogenous or from dietary sources, both are transported in the liver, where their first hydroxylation at the carbon in position 25 takes place, producing 25-hydroxyvita- $\min \mathrm{D}$ (25[OH]D) [3]. 25[OH]D is the major circulating form of vitamin $\mathrm{D}$, and its concentration in serum reflects the vitamin D stores in humans. Vitamin D deficiency is a worldwide health problem that affects not only musculoskeletal health but also it may be associated with a wide range of acute and chronic diseases. A recent study reported the association of vitamin D deficiency with the risk 
of type 2 diabetes mellitus in Bangladeshi population [4]. Adequate vitamin D status is the key parameter for proper bone health in early life and reduced risk for developing osteoporosis later. It also prevents secondary hyperparathyroidism. Vitamin D is one of the most important contributors to calcium (Ca) homeostasis [5].

Vitamin D deficiency during pregnancy is not only a danger for maternal skeletal preservation [6] but also may be associated with an increased risk of preeclampsia [7], insulin resistance and gestational diabetes mellitus [8]. Throughout pregnancy, a woman needs to maintain her vitamin D necessities to support her own and her fetus [9]. Vitamin D status during pregnancy is vital to maternal health, fetal development, and optimal neonatal outcomes [10]. Numerous observational studies indicate an epidemic of vitamin D deficiency in pregnant women in different countries $[11,12]$. Studies have shown that vitamin D-deficient mothers develop secondary hyperparathyroidism, which leads to transitory hypoparathyroidism and hypocalcemia among the neonates [13]. During pregnancy, adequate vitamin D guarantees proper maternal responses to the calcium demands of the fetus and neonate as neonatal vitamin D stores are entirely dependent on the mothers [9]. Many clinical studies support that severe maternal vitamin D deficiency causes hypocalcemia and congenital rickets in infants. Also, there is [14] evidence to support an association between the prenatal vitamin D environment and the risk of later schizophrenia development [15]. Grant and his colleagues have reported that maternal vitamin D deficiency is a risk factor for infantile autism disease [16]. Mothers with low vitamin D intake during pregnancy, children are found to be more common suffering eczema, hay fever or allergic rhinitis [17].

Adequate maternal calcium and vitamin D intake are associated with appropriate birth weight [5]. In Asian populations living in England, half of the children having low hemoglobin level are suffering from vitamin D deficiency [18]. Lower serum 25-hydroxyvitamin D [25(OH)D] concentrations during pregnancy are associated with poor health outcomes for pregnant women and newborns [19]. Pregnant women and newborns are recognized as populations at increased risk of poor vitamin D status [20]. Given the potential for poor vitamin D status during pregnancy to affect maternal and child outcomes that remain important determinants of global health, our objective was to determine the status of Bangladeshi pregnant women and their newborns to join the global summary of vitamin D status in pregnant women and newborns.

\section{Aim of the Study}

The aim of this study was to evaluate maternal and umbilical cord blood vitamin D concentrations and its association with birth weight.

\section{Material and Methods}

Study design

Dhaka, the capital city of Bangladesh $\left(23^{\circ} 42^{\prime} 0^{\prime \prime} \mathrm{N} 90^{\circ} 22^{\prime} 30^{\prime \prime} \mathrm{E}\right)$ experiences a hot, wet and humid tropical climate. The city has a distinct monsoonal season, with an annual average temperature of $25^{\circ} \mathrm{C}\left(77^{\circ} \mathrm{F}\right)$ and monthly means varying between $18^{\circ} \mathrm{C}\left(64^{\circ} \mathrm{F}\right)$ in January and $29^{\circ} \mathrm{C}\left(84^{\circ} \mathrm{F}\right)$ in August. Although the winter season in Bangladesh is not significantly cold but to avoid the seasonal effect on serum $250 \mathrm{H}$ [D] concentration, samples were collected from April to October 2016. Pre-delivery maternal venous blood within a week before delivery and paired matched neonatal cord blood samples were collected from 75 pregnant women with no history of chronic diseases before pregnancy. Samples were collected from Islami Bank Hospital, Dhaka and Azimpur Maternity Clinic, Dhaka. Pregnant women with multiple gestation, gestational diabetes and complicated pregnancy were excluded from the study. All participants were explained about the nature of the study, and informed consent was obtained. They completed a structured questionnaire covering information on age, height, weight, education, dressing style, occupation, and frequency of child. No specific nutritional data was taken. But from verbal communication it's seen that nearly all patients take 9 cup of cooked rice, 3 cups of vegetable, and approximately 60 gram of protein every day. No subject reported any history of allergy or smoking. This study was approved by the ethical review committee of faculty of Biological Sciences, University of Dhaka.

\section{Laboratory analyses and data collection}

Maternal venous blood and cord blood samples were collected; centrifuged and appropriate aliquots of serum were taken in Eppendorf tubes and stored at $-20^{\circ} \mathrm{C}$. Serum vitamin $\mathrm{D}$ was measured using High-Performance Liquid Chromatography (HPLC). The sample was prepared according to the method described by Turpeinen., et al. (2003) [21]. The mobile phase was HPLC grade methanol. For separation, we used C18 column $(100 \times 4.6 \mathrm{~mm}, 3 \mu \mathrm{m}$ particle size). Injection volume was 20 microliters and the runtime was 10 minutes. For detection, the wavelength of UV detector was set to $254 \mathrm{~nm}$. For standard curve preparation we used five different concentration of vitamin D standard $(10,20,40,80,120 \mathrm{ng} / \mathrm{mL})$. The 
curve was linear for area vs concentration data and the goodness of fit $\left(\mathrm{R}^{2}\right)$ was 0.9985 . The lower detection limit was $2.0 \mathrm{ng} / \mathrm{mL}$. Five (5) ng internal standard was used for each sample. Before running the sample, three replicates of a standard were used to evaluate the relative standard deviation ( $\pm 2 \%$ ). Serum calcium, inorganic phosphorus and alkaline phosphatase (ALP) activity was measured using the commercially available kit supplied by ThermoFisher Scientific.

\section{Statistical analyses}

Data were presented as mean \pm SD or percentage (\%). The mean of two groups were compared using unpaired t-test. Linear correlation and regression were used to test the correlation between the measured parameters with graph pad prism 6. Data were tabulated and statistically analyzed with Microsoft Excel 2013. P < 0.05 was considered significant.

\section{Results}

In light of the ongoing debate on the optimal vitamin D concentration in pregnant women, most experts are of the opinion that the $25[\mathrm{OH}] \mathrm{D}$ concentration in maternal blood should exceed $30 \mathrm{ng} / \mathrm{mL}$ $[22,23]$. However, other authors claim that maternal concentration that fully normalizes vitamin D metabolism and calcium homeostasis is at least $40 \mathrm{ng} / \mathrm{mL}$ [24], and still others that > $20 \mathrm{ng} / \mathrm{mL}$ is necessary to prevent vitamin D deficiency in the newborn [25].

The following criteria of maternal serum $25[\mathrm{OH}]$ D concentration were used in this study: recommended level $>30 \mathrm{ng} / \mathrm{mL}$, insufficiency 20 - $30 \mathrm{ng} / \mathrm{mL}$, deficiency < $20 \mathrm{ng} / \mathrm{mL}$ [26]. For umbilical cord blood, $\geq 20 \mathrm{ng} / \mathrm{mL}$ was the recommended level and lower values signified vitamin D deficiency [27].

\section{Maternal and neonatal characteristics}

Maternal and neonatal characteristics are presented in table 1. Mean age of the study subjects was $24.78 \pm 3.67$ years $(95 \% \mathrm{CI}$ 22.68 to 24.68 ) (range: $18-32$ years), most of them were housewives $(72 \%)$. They were divided into three groups according to their educational status like primary (5 years of education), secondary (10 years of education) and higher secondary (12 years of education). Almost half of the study participants (48\%) passed higher secondary or more and $40 \%$ of the study subjects completed their high school education and the rest (12\%) has completed primary education. Among the study subjects, $68 \%$ are Primigravida (first time pregnancy). In Bangladesh, most women wear saree and salwar kamiz. Specially, after marriage, they prefer saree. In our study, $60 \%$ of the study subjects used to wear hizab with saree or salwar kamiz when going outside.
Table 1: Maternal and neonatal demographic characteristics.

\begin{tabular}{|l|c|}
\hline Maternal Characteristics (n = 75) & \\
\hline Age (in years) mean \pm SD & $24.78 \pm 3.67$ \\
\hline Education (\%) & 12 \\
Primary & 40 \\
Secondary & 48 \\
\hline Higher secondary & \\
\hline Occupation (\%) & 72 \\
Housewife & 28 \\
\hline Working mother & \\
\hline Dressing style (\%) & 85 \\
Saree & 15 \\
Salwar kameeze & 60 \\
Use saree/salwar kameeze with hizab & \\
\hline Frequency of child (\%) & 62 \\
Primigravida & 38 \\
Multigravida & $75 \%$ \\
\hline Supplementation with multivitamin & \\
preparation (\%) & \\
\hline Supplementation with single- component & \\
vitamin-D preparation (\%) & \\
\hline Time outside between 8 a.m. and 5 p.m. & 1.5 hr-3.0 hr \\
\hline Neonatal Characteristics (n=75) & \\
\hline Sex of newborns (\%) & \\
Males & \\
Females & \\
\hline Weight of the newborn (kg) & $22 \%$ \\
\hline 2.50 & \\
$<2.50$ & \\
\hline Head circumference in newborn (cm), \\
mean \pm SD & \\
\hline Body length of newborn (cm), mean \pm SD & $49.35 \pm 1.64$ \\
\hline
\end{tabular}

We also analyzed maternal demographic characteristics between mother of LBW baby group and mother of NBW baby group. There was no significant difference between these two groups on education, occupation, clothing, presence of supplement, outing time, and BMI (Table 2).

\section{Maternal vs neonatal (Umbilical cord blood) 25[0H]D}

Mean level of serum 25[OH] D in mothers was $46.45 \pm 5.02$ $\mathrm{ng} / \mathrm{ml}$ and in their neonates was $21.89 \pm 2.27 \mathrm{ng} / \mathrm{ml}$. The serum $25[\mathrm{OH}] \mathrm{D}$ level of the mothers and the neonates were significantly associated $(\mathrm{P}<0.01)$ with a linear correlation coefficient of $\mathrm{r}=0.49$ (Figure 1). We found no significant difference in 25 [OH] D levels due to dressing style. 
Table 2: Maternal demographic parameters based on mother of LBW baby and mother of NBW baby.

\begin{tabular}{|c|c|c|c|}
\hline Parameters & $\begin{array}{c}\text { Mother of LBW } \\
\text { baby }(n=17)\end{array}$ & $\begin{array}{c}\text { Mother of } \\
\text { normal weight } \\
\text { baby }(n=58)\end{array}$ & $P$ value \\
\hline Age & $23.27 \pm 3.165$ & $23.79 \pm 3.826$ & ns \\
\hline \multicolumn{4}{|l|}{ Education } \\
\hline Primary (\%) & 25 & 18 & \\
\hline Secondary (\%) & 33 & 39 & ns \\
\hline $\begin{array}{l}\geq \text { Higher Sec- } \\
\text { ondary (\%) }\end{array}$ & 42 & 43 & \\
\hline \multicolumn{4}{|l|}{ Occupation } \\
\hline Housewife (\%) & 82 & 73 & ns \\
\hline $\begin{array}{l}\text { Working } \\
\text { mother (\%) }\end{array}$ & 18 & 27 & \\
\hline Clothes & & & ns \\
\hline Saree (\%) & 83 & 79 & \\
\hline $\begin{array}{l}\text { Salwar kameeze } \\
(\%)\end{array}$ & 17 & 21 & \\
\hline $\begin{array}{l}\text { Presence of } \\
\text { supplement (\%) }\end{array}$ & 69 & 76 & ns \\
\hline Outing time & $2.21 \pm 0.57$ & $2.29 \pm 0.68$ & ns \\
\hline BMI & $23 \pm 2.366$ & $23.77 \pm 2.334$ & ns \\
\hline
\end{tabular}

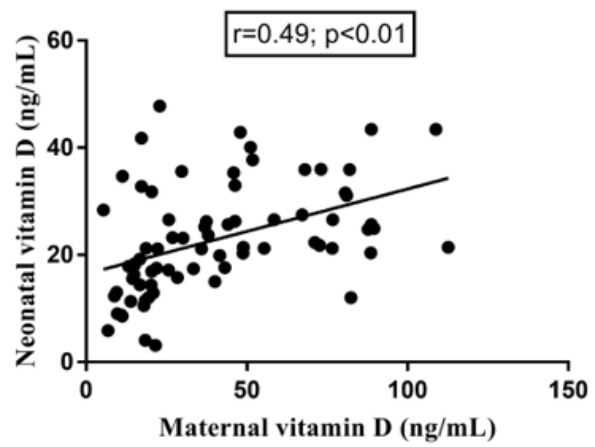

Figure 1: Correlation between maternal and neonatal vitamin D. There was low degree of positive correlation between maternal and neonatal serum vitamin D level $(r=0.49, \mathrm{p}<0.01)$.
According to serum level of $25[\mathrm{OH}] \mathrm{D}$, study mothers were divided into three groups like sufficient $(>30 \mathrm{ng} / \mathrm{mL})$, insufficient $(20-30 \mathrm{ng} / \mathrm{mL})$ and deficient $(<20 \mathrm{ng} / \mathrm{mL})$ groups. More than half of the study mothers (54\%) showed the recommended or sufficient level of serum $25[\mathrm{OH}] \mathrm{D}$ level, $20 \%$ of the study mothers were insufficient, whereas $26 \%$ of the study mothers were deficient in serum 25[OH] D level. Neonates were divided into two groups depending on the umbilical cord blood 25[OH]D contents like recommended or sufficient group ( $\geq 20 \mathrm{ng} / \mathrm{mL}$ ) and deficient group $<20$ $\mathrm{ng} / \mathrm{mL}$ ). Almost half of the neonates (54\%) of the study group were deficient in 25[OH]D level and $46 \%$ of the neonates were found to have recommended or sufficient level of 25[OH]D.

\section{Maternal 25[0H] D level and birth weight}

The mean birth weight of neonates was $2.83 \mathrm{~kg} \pm 0.38(95 \%$ CI 2.72 to 2.94 ) (range: $1.8-3.6 \mathrm{~kg}$ ) and $22 \%$ of the neonates have low birth weight (LBW) (2.33 \pm 0.17$)$ (95\% CI 2.23 to 2.43). Average birth weight of normal babies was $2.97 \pm 0.30$ (95\% CI 2.876 to 3.064). The mean maternal 25[OH]D level of mothers with normal birth weight babies ( $\mathrm{n}=58 ; 77.33 \%$ ) was significantly higher $(50.41 \pm 5.00 \mathrm{ng} / \mathrm{mL})$ than that $(28.24 \pm 6.87 \mathrm{ng} / \mathrm{mL})$ of mothers with low birth weight (LBW) babies $(\mathrm{p}<0.001)$. There was a high degree of positive correlation between maternal 25[0H] D status with neonate's birth weight $(r=0.593, \mathrm{p}<0.01$ ) (Figure 2). Mothers with LBW babies had lower calcium but higher phosphorous and ALP activity compared to mothers with NBW babies (Table 3).

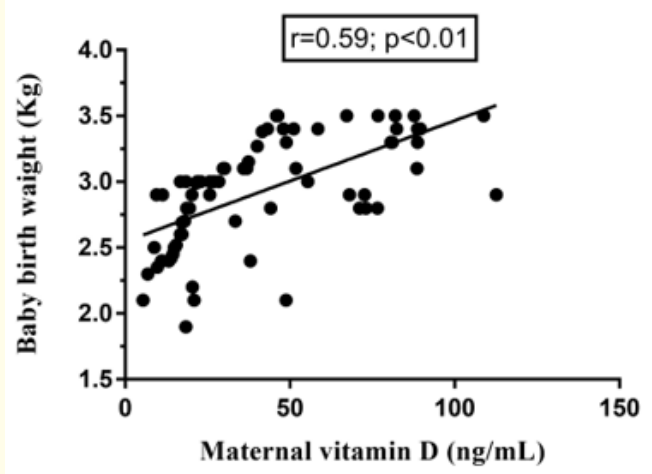

Figure 2: Correlation between maternal vitamin D and neonatal birth weight. There was high degree of positive correlation between maternal vitamin $\mathrm{D}$ and neonatal birth weight $(r=0.59$, $\mathrm{p}<0.01$ ). 
Association of Maternal Vitamin D with Neonatal Vitamin D Status and Birth Weight in Urban Population of Bangladesh: A Cross Sectional Study

Table 3: Maternal and neonatal status of $250 \mathrm{H}[\mathrm{D}]$, calcium, phosphorus, and alkaline phosphates according to birth weight.

\begin{tabular}{|c|c|c|c|c|c|c|}
\hline \multirow[b]{2}{*}{ Parameters } & \multicolumn{2}{|c|}{ Cord blood } & \multirow[t]{2}{*}{ p-value } & \multicolumn{2}{|c|}{ Venous blood } & \multirow[t]{2}{*}{ p-value } \\
\hline & $\begin{array}{c}\text { Birth weight < } \\
2.5 \mathrm{Kg} ; \mathrm{n}=17\end{array}$ & $\begin{array}{c}\text { Birth weight } \geq \\
2.5 \mathrm{Kg} ; \mathrm{n}=58\end{array}$ & & $\begin{array}{c}\text { Birth weight < } \\
2.5 \mathrm{Kg} ; \mathrm{n}=17\end{array}$ & $\begin{array}{c}\text { Birth weight } \geq \\
2.5 \mathrm{Kg} ; \mathrm{n}=58\end{array}$ & \\
\hline $250 H[D](n g / m L)$ & $13.8 \pm 3.1$ & $22.24 \pm 1.84$ & $\mathrm{P}<0.0001$ & $28.24 \pm 6.87$ & $50.41 \pm 5.00$ & $\mathrm{P}<0.0001$ \\
\hline Calcium (mg/dL) & $7.47 \pm 0.25$ & $8.54 \pm 0.24$ & $\mathrm{P}<0.05$ & $8.63 \pm 0.19$ & $9.99 \pm 0.32$ & $\mathrm{P}<0.0001$ \\
\hline Phosphorus (mg/dL) & $5.02 \pm 0.31$ & $6.81 \pm 0.39$ & $\mathrm{P}<0.0001$ & $4.27 \pm 0.25$ & $4.97 \pm 0.16$ & $\mathrm{P}<0.0001$ \\
\hline Alkaline phosphatase (U/L) & $49.49 \pm 0.87$ & $40.78 \pm 3.42$ & $\mathrm{P}<0.0001$ & $90.29 \pm 4.33$ & $69.47 \pm 4.72$ & $\mathrm{P}<0.0001$ \\
\hline
\end{tabular}

Among the study subjects, $22.6 \%(\mathrm{n}=17)$ mothers gave birth to LBW babies (birth weight $<2.5 \mathrm{Kg}$ ). Along with the lower $25[\mathrm{OH}]$ $\mathrm{D}$ status in low birth weight neonates (assessed in cord blood samples), other biochemical parameters like calcium, phosphorous, and alkaline phosphatase activity were significantly different when compared to normal birth weight neonates (Table 3). When we compared babies born with low birth weight with those with normal birth weight, we found significantly lower serum 25[OH]D $(\mathrm{p}<0.0001)$, lower serum calcium levels ( $\mathrm{p}=0.0131)$, lower phosphorous ( $\mathrm{p}<0.0001)$, and higher alkaline phosphatase activity ( $\mathrm{p}$ $<0.0001$ ). Similar pattern was found when we compared venous blood of corresponding mothers.

Relationship between maternal $25[0 \mathrm{H}]$ D status with maternal and neonatal biochemical parameters

Correlation analysis between maternal 25[OH] D and other biochemical parameters shows that maternal 25[OH] D have significant positive correlation with maternal calcium $(r=0.35, p<0.05)$ and maternal phosphorus $(r=0.336, p<0.05)$. On the other hand, a significant negative correlation was found between maternal Vitamin D and maternal ALP activity $(r=-0.53, \mathrm{p}<0.05)$. The maternal vitamin $\mathrm{D}$ has an impact on neonatal serum parameters. Maternal serum 25[OH] D status showed a positive correlation with neonatal $25[\mathrm{OH}] \mathrm{D}(\mathrm{r}=0.49, \mathrm{p}<0.01)$ and neonatal calcium $(\mathrm{r}=0.195, \mathrm{p}<$ 0.05). Maternal 25[OH] D level showed a negative correlation with neonatal phosphorus $(\mathrm{r}=0.24, \mathrm{p}<0.05)$ and ALP activity $(\mathrm{r}=0.35$, $\mathrm{p}<0.05$ ).

\section{Discussion and Conclusion}

Most of the studies on vitamin D status in the general population identified women and newborns as groups at increased risk of serum 25[OH]D concentrations [28,29]. Vitamin D deficiency is prevalent in various parts of the world including South Asia. Bangladesh is a tropical country of South Asia where sunlight is abundant almost year round; therefore the extent of vitamin D deficiency is rather surprising in Bangladeshi population given its geographic latitude ( $23^{\circ} 42^{\prime} 0^{\prime \prime} \mathrm{N} 90^{\circ} 22^{\prime} 30^{\prime \prime} \mathrm{E}$ ), which support cutaneous vitamin D synthesis year-round. However, a high prevalence of vitamin D deficiency in Bangladeshi women has been reported in some studies [30,31]. In Bangladesh, socioeconomic status have been reported to impact the level of serum vitamin $\mathrm{D}$, calcium and alkaline phosphatase (ALP) activity in pregnant women [32].

More than half of the study mothers (54\%) showed the recommended or sufficient level of serum 25[OH] D level, $20 \%$ of the study mothers were insufficient, whereas $26 \%$ of the study mothers were deficient in serum 25[OH] D levels. The mean value of maternal 25[OH] D level was $45.53 \pm 30.81 \mathrm{ng} / \mathrm{mL}$ and the neonatal 25[OH] D level was $22.16 \pm 12.37 \mathrm{ng} / \mathrm{mL}$. Most of the authors recommend that the pregnant mother should receive 2000 IU of $25[\mathrm{OH}] \mathrm{D}$ daily during the third trimester [33]. In the present study, $75 \%$ of the pregnant mothers were found to intake 200 IU of vitamin D per day as a component of multivitamin preparation from 15 to 20 weeks to the full term of pregnancy which may contribute to the maternal 25[OH] D level. This is a positive sign of health care in Bangladesh. With the growing economy of the country, consciousness about health care is also growing among people. High income group people usually take their medical care from private hospitals which are expensive but in our study most of the subjects were from moderate to low income group.

The neonates derive the vitamin $\mathrm{D}$ through the trans-placental passage of vitamin D metabolites during intrauterine life. The major metabolite to cross the placenta is $25[\mathrm{OH}] \mathrm{D}$ with cord level being approximately two-thirds of those found in the mothers [34]. Thus, unless exogenous vitamin D is provided, the vitamin D of the neonates will drop as its half-life is only 3 - 4 weeks. The vitamin D content of the breast milk has been estimated to be between 20 
and $60 \mathrm{Iu} / \mathrm{L}$ [35] and is not adequate for meeting the requirement of a growing baby [36]. The infants of the mothers with adequate $25[\mathrm{OH}] \mathrm{D}$ are likely to improve their vitamin D status faster than those of the mothers with lower serum 25[OH] D level.

Vitamin D metabolism is enhanced during pregnancy and lactation. It crosses the placenta, so the vitamin D level of the newborn is entirely dependent on the maternal 25[OH] D level [37]. Like most of the other studies [38], we found the higher maternal 25[OH] D levels compared to neonatal levels (Figure 1). When the mean value of maternal vitamin D level was $29.61 \mathrm{ng} / \mathrm{ml}$, then the concentration in the cord blood was found to be $21.05 \mathrm{ng} / \mathrm{ml}$; but when the maternal level was found to be $91.66 \mathrm{ng} / \mathrm{ml}$ the concentration in the cord blood is found $30.57 \mathrm{ng} / \mathrm{ml}$. Serum 25[OH] D level in cord blood is directly related with relatively lower maternal vitamin D levels but when the maternal $25[\mathrm{OH}] \mathrm{D}$ level is relatively higher, the cord blood level not elevated in the similar fashion. These findings may be due to some other factors, including the availability and function of vitamin $\mathrm{D}$ binding protein.

Lower 25[OH] D levels in low birth weight groups (both neonate and mothers) are associated with lower calcium, phosphorus levels and higher ALP activity. When we compared the biochemical parameters in cord blood of LBW groups with the normal birth weight groups, there was a significantly higher level of vitamin D, calcium and phosphorus in normal babies than LBW babies ( $\mathrm{p}<$ 0.05). Mothers of LBW babies $(<2.5 \mathrm{Kg}$ ) were found to have low 25[OH] D level. A study conducted by Mannion., et al. showed that the birth weight had been higher in women who consumed food fortified with serum 25[OH] D than those who did not [39]. We found significantly lower calcium and phosphorus level in mothers of LBW babies than the mother of normal weight babies $(\mathrm{p}<$ 0.05). As vitamin $D$ facilitates the intestinal absorption of calcium and phosphorus, lower levels of calcium and phosphorus in mothers of LBW babies may be due to lower levels of vitamin D. A study on Pakistani population revealed that mothers of LBW babies have significantly lower levels of calcium and phosphorus than the mothers of normal babies [40].

From our study, it can be said that Maternal low vitamin D level have a negative impact on neonatal birthweight and other parameters like calcium and alkaline phosphatase. Further study on large population may help to strengthen our findings in future.

\section{Conflict of Interest Statement}

The authors declare no conflict of interest.

\section{Acknowledgements}

This research was supported by the Ministry of Science and Technology, Government of Peoples Republic of Bangladesh (Grant No: 39.009.006-01.00.049./MED'S-26).We would like to acknowledge the participants of the study.

\section{Bibliography}

1. Bouillon R., et al. "Association Structure-function relationships in the vitamin D endocrine system". Endocrine Review 16.2 (1995): 200-257.

2. Haddad JG. "Vitamin D--solar rays, the Milky Way, or both?" The New England Journal of Medicine 326.18 (1992): 12131215.

3. Holick MF. "Vitamin D: A millenium perspective". Journal of Cellular Biochemistry 88.2 (2003.): 296-307.

4. Rahman MM., et al. "Association of vitamin D and vitamin D binding protein (DBP) gene polymorphism with susceptibility of type 2 diabetes mellitus in Bangladesh". Gene 636 (2017): 42-47.

5. Thorne-Lyman A and WW Fawzi. "Vitamin D during pregnancy and maternal, neonatal and infant health outcomes: a systematic review and meta-analysis". Paediatric and Perinatal Epidemiology 26 (2012): 75-90.

6. Javaid MK., et al. "Maternal and Seasonal Predictors of Change in Calcaneal Quantitative Ultrasound during Pregnancy". The Journal of Clinical Endocrinology and Metabolism 90.9 (2005): 5182-5187.

7. Bodnar LM., et al. "High prevalence of vitamin D insufficiency in black and white pregnant women residing in the northern United States and their neonates". Journal of Nutrition 137.2 (2007): 447-452.

8. Clifton-Bligh RJ., et al. "Association Maternal vitamin D deficiency, ethnicity and gestational diabetes". Diabetic Medicine 25.6 (2008): 678-684.

9. Kovacs CS. "Vitamin D in pregnancy and lactation: maternal, fetal, and neonatal outcomes from human and animal studies". American Journal of Clinical Nutrition 88.2 (2008.): 520s-528s.

10. Camadoo L., et al. "Association Maternal vitamin D deficiency associated with neonatal hypocalcaemic convulsions". Nutrition Journal 6 (2007): 23.

11. Kazemi A., et al. "High prevalence of vitamin D deficiency among pregnant women and their newborns in an Iranian population". Journal of Women's Health (Larchmt) 18.6 (2009): 835-839.

Citation: Md. Mostafijur Rahman and Saimon Miah., et al. "Association of Maternal Vitamin D with Neonatal Vitamin D Status and Birth Weight in Urban Population of Bangladesh: A Cross Sectional Study". Acta Scientific Paediatrics 3.12 (2020): 19-26. 
12. Vandevijvere S., et al. "High prevalence of vitamin D deficiency in pregnant women: a national cross-sectional survey". PLoS One 7.8 (2012.): e43868.

13. Okonofua F., et al. "Parathyroid hormone and neonatal calcium homeostasis: evidence for secondary hyperparathyroidism in the Asian neonate". Metabolism 35.9 (1986): 803-806.

14. Innes, A.M., et al. "Congenital rickets caused by maternal vitamin D deficiency". Paediatric Child Health 7.7 (2002.): 455458.

15. McGrath JJ., et al. "Neonatal vitamin D status and risk of schizophrenia: a population-based case-control study". Archives of General Psychiatry 67.9 (2010.): 889-894.

16. Grant KA., et al. "Maternal prenatal anxiety, postnatal caregiving and infants' cortisol responses to the still-face procedure". Developmental Psychobiology 51.8 (2009): 625-637.

17. Camargo CA Jr., et al. "Maternal intake of vitamin D during pregnancy and risk of recurrent wheeze in children at $3 \mathrm{y}$ of age". American Journal of Clinical Nutrition 85.3 (2007.): 78895.

18. Lawson M., et al. "Dietary and lifestyle factors affecting plasma vitamin D levels in Asian children living in England". European Journal of Clinical Nutrition 53.4 (1999): 268-272.

19. Aghajafari F., et al. "Association between maternal serum 25-hydroxyvitamin D level and pregnancy and neonatal outcomes: systematic review and meta-analysis of observational studies". BMJ 346 (2013): f1169.

20. Dawodu A and CL Wagner. "Mother-child vitamin D deficiency: an international perspective". Archives of Disease in Childhood 92.9 (2007): 737-740.

21. Turpeinen U., et al. "Determination of 25-hydroxyvitamin D in serum by HPLC and immunoassay". Clinical Chemistry 49.9 (2003): 1521-1524.

22. Karras SN., et al. "Maternal vitamin D status during pregnancy: the Mediterranean reality". European Journal of Clinical Nutrition 68.8 (2014): 864-869.

23. Lu M., et al. "Association between vitamin D status and the risk of gestational diabetes mellitus: a meta-analysis". Archives of Gynecology and Obstetrics 293.5 (2016): 959-966.

24. Hollis BW and CL Wagner. "New insights into the vitamin D requirements during pregnancy". Bone Research 5 (2017): 17030.
25. við Streym S., et al. "Maternal and infant vitamin D status during the first 9 months of infant life-a cohort study". European Journal of Clinical Nutrition 67.10 (2006): 1022-1028.

26. Skowronska-Jozwiak E., et al. "Effects of maternal vitamin D status on pregnancy outcomes, health of pregnant women and their offspring". Neuro Endocrinology Letter 35.5 (2014.): $367-$ 372 .

27. Kiely M., et al. "Vitamin D metabolite concentrations in umbilical cord blood serum and associations with clinical characteristics in a large prospective mother-infant cohort in Ireland". The Journal of Steroid Biochemistry and Molecular Biology 167 (2017): 162-168.

28. Hagenau T., et al. "Global vitamin D levels in relation to age, gender, skin pigmentation and latitude: an ecologic metaregression analysis". Osteoporosis International 20.1 (2009.): 133-140.

29. Mithal A., et al. "Global vitamin D status and determinants of hypovitaminosis D”. Osteoporosis International 20.11 (2009): 1807-20.

30. Islam MZ., et al. "Hypovitaminosis D is common in both veiled and nonveiled Bangladeshi women". Asia Pacific Journal of Clinical Nutrition 15.1 (2006.): 81.

31. Islam MZ., et al. "Vitamin D deficiency and low bone status in adult female garment factory workers in Bangladesh". British Journal of Nutrition 99.6 (2008.): 1322-1329.

32. Islam MZ., et al. "Vitamin D deficiency: a concern in premenopausal Bangladeshi women of two socio-economic groups in rural and urban region". European Journal of Clinical Nutrition 56.1 (2002.): 51-6.

33. Ala-Houla M. "Maternal compared with infant vitamin D supplementation". Archives of Disease in Childhood 58 (1983.): 573-574.

34. Reeve LE., et al. "Vitamin D of human milk: identification of biologically active forms". American Journal of Clinical Nutrition 36.1 (1982.): 122-126.

35. Ala-Houhala, M. "25-Hydroxyvitamin D levels during breastfeeding with or without maternal or infantile supplementation of vitamin D". Journal of pediatric gastroenterology and nutrition 4.2 (1985.): 220-226.

36. Cockburn F., et al. "Maternal vitamin D intake and mineral metabolism in mothers and their newborn infants". British Medical Journal 281.6232 (1980.): 11-14. 
37. Karatekin G., et al. "Association of subclinical vitamin D deficiency in newborns with acute lower respiratory infection and their mothers". European Journal of Clinical Nutrition 63.4 (2009.): 473-477.

38. Parlak M., et al. "Severe vitamin D deficiency among pregnant women and their newborns in Turkey". The Journal of Maternal-Fetal and Neonatal Medicine 28.5 (2015): 548-551.

39. Mannion CA., et al. "Association of low intake of milk and vitamin D during pregnancy with decreased birth weight". CMAJ 174.9 (2005): 1273-1277.

40. Agbonlahor OJ and MA Emokpae. "Levels of Some Essential Elements in Pregnant Women and Association with Low Birth Weight of Babies in Benin City". Pakistan Journal of Nutrition 15.6 (2016): 585 .

\section{Assets from publication with us}

- Prompt Acknowledgement after receiving the article

- Thorough Double blinded peer review

- Rapid Publication

- Issue of Publication Certificate

- High visibility of your Published work

Website: www.actascientific.com/

Submit Article: www.actascientific.com/submission.php

Email us: editor@actascientific.com

Contact us: +919182824667 